\title{
Heritabilitas, Korelasi, dan Sidik Lintas Berbagai Karakter Tomat pada Kondisi Naungan dan Tanpa Naungan
}

\author{
Heritability, Correlation, and Path Analysis on Various Characters of Tomato \\ (Solanum lycopersicum) under Shading and Normal Condition
}

\author{
Arya Widura Ritonga ${ }^{1,2}$, Muhammad Achmad Chozin ${ }^{2 *}$, Muhamad Syukur ${ }^{2}$, \\ Awang Maharijaya ${ }^{2}$, dan Sobir ${ }^{2}$
}

Diterima 26 Juli 2018/Disetujui 02 April 2019

\begin{abstract}
Character selection information is essential for plant breeding program. SSH3 tomato genotype (shade-tolerant genotype), 4974 (shade-sensitive genotype), and F2 population derived from "SSH3 $x$ 4974" were evaluated to estimate the heritability, correlation, direct and indirect effects between yield and various yield atributting characters in tomato under shading and normal condition at Pasir Kuda Station, Bogor Agriculture University, West Java, Indonesia from July until October 2016. The results showed that plant height, leaf length, leaf width, leaf weight, specific leaf weight, fruit weight, fruit number per plant and fruit weight per plant had high heritability under normal condition, while plant height, fruit set, fruit number of plant and fruit weight per plant had high heritability under shading condition. High direct positive effect on yield per plant was resulted from fruit weight and fruit number of plant under shading and normal condition, while leaf width had direct positive effect on fruit weight per plant only under shading condition. High indirect positive effect on yield per plant was resulted from fruit set, fruit length and fruit diameter under shading and normal condition, while plant heigh had high indirect effect on yield per plant only under shading condition. Fruit set, fruit weight, and fruit number per plant characters were potential to be used as character selection for tomato productivity in normal conditions. Plant height, fruit set and fruit number per plant were potential to be used as character selection for tomato productivity under shading condition.
\end{abstract}

Keywords: direct effect, fruit set, indirect effect, low light tolerant

\begin{abstract}
ABSTRAK
Informasi tentang karakter seleksi sangat diperlukan dalam suatu program pemuliaan. Genotipe tomat SSH3 (suka naungan), genotipe 4974 (peka naungan) dan populasi F2 turunan hasil persilangan genotipe SSH3 x 4974 digunakan untuk menduga nilai heritabilitas, pengaruh langsung dan pengaruh tidak langsung terhadap karakter hasil tomat pada kondisi naungan paranet 50\% dan tanpa naungan. Penanaman dilakukan di Kebun Percobaan PKHT-IPB Pasir Kuda pada Juli sampai Oktober 2016. Nilai heritabilitas tinggi (>50\%) dihasilkan oleh tinggi tanaman, panjang daun, lebar daun, luas daun, bobot daun, bobot daun spesifik, bobot buah, fruit set, jumlah dan bobot buah per tanaman tomat pada kondisi tanpa naungan. Nilai heritabilitas tinggi ( $>50 \%)$ pada naungan paranet 50\%, dihasilkan oleh tinggi tanaman, fruit set, jumlah dan bobot buah per tanaman. Karakter bobot buah dan jumlah buah per tanaman memiliki pengaruh langsung yang tinggi dan positif terhadap bobot buah per tanaman tomat pada kondisi tanpa naungan dan naungan paranet 50\%, sementara lebar dan luas daun memiliki pengaruh langsung yang tinggi dan positif terhadap bobot buah per tanaman tomat hanya pada naungan paranet 50\%. Karakter panjang buah, diameter buah, dan fruit set memiliki pengaruh tidak langsung yang tinggi dan positif terhadap bobot buah per tanaman pada kondisi tanpa naungan dan naungan paranet 50\%, sementara tinggi tanaman memiliki pengaruh tidak langsung yang tinggi dan positif terhadap bobot buah per tanaman tomat hanya pada naungan paranet 50\%. Karakter fruit set, bobot
\end{abstract}


buah, dan jumlah buah per tanaman potensial dijadikan karakter seleksi untuk produktivitas tomat pada kondisi tanpa naungan. Karakter tinggi tanaman, fruit set dan jumlah buah per tanaman potensial dijadikan karakter seleksi untuk produktivitas tomat pada naungan paranet $50 \%$.

Kata kunci: fruit set, pengaruh langsung, pengaruh tidak langsung, toleran naungan

\section{PENDAHULUAN}

Sebagian besar penduduk Indonesia bekerja di bidang pertanian, namun luas kepemilikan lahan pertanian oleh lebih dari 50\% petani Indonesia tidak sampai 0.5 ha (Susilowati dan Maulana, 2012). Optimasi pemanfaatan lahan pertanian perlu dilakukan untuk dapat meningkatkan pendapatan petani Indonesia. Salah satunya dengan pemanfaatan varietas tanaman toleran intensitas cahaya rendah yang berdaya hasil tinggi pada sistem budidaya tumpang sari.

Tanaman tomat merupakan salah satu tanaman yang potensial dikembangkan pada sistem budidaya tumpang sari karena terdapat genotipe-genotipe tomat yang toleran (produktivitas menurun $<20 \%$ pada kondisi cekaman) bahkan senang (produktivitas semakin tinggi pada kondisi cekaman) dengan naungan hingga 50\% (Baharudin et al., 2014; Sulistyowati et al., 2016a). Meskipun demikian belum ada varietas tomat toleran intensitas cahaya rendah berdaya hasil tinggi yang dilepas oleh Kementerian Pertanian RI. Perakitan varietas tomat toleran naungan yang berdaya hasil tinggi penting untuk dilakukan.

Informasi pengaruh naungan terhadap pertumbuhan dan hasil tanaman tomat seperti penurunan produktivitas, luas daun, kandungan klorofil (Sandri et al., 2003; Baharudin et al., 2014; Ilic et al., 2015; Sulistyowati et al., 2016b), peningkatan kualitas buah (Peet, 1992; Ilic et al., 2015), peningkatan tinggi tanaman telah banyak diketahui. Namun, kegiatan pemuliaan tanaman tomat toleran naungan yang berdaya hasil tinggi masih sulit dilakukan karena belum adanya informasi tentang karakter seleksi untuk pemuliaan tanaman tomat toleran naungan yang berdaya hasil tinggi. Suatu karakter dapat digunakan sebagai karakter seleksi umumnya karakter yang memiliki nilai heritabilitas yang tinggi dan memiliki pengaruh langsung dan tidak langsung yang kuat dan positif terhadap idiotipe yang diinginkan. Penelitian ini bertujuan memperoleh informasi tentang heritabilitas, koefisien korelasi dan koefisien lintas berbagai karakter tomat pada kondisi tanpa naungan dan naungan paranet $50 \%$.

\section{BAHAN DAN METODE}

Penelitian ini dilaksanakan di Kebun Percobaan PKHT-IPB Pasir Kuda, Ciomas, Bogor yang berada pada ketinggian $250 \mathrm{mdpl}$ pada Juli sampai Oktober 2016. Genotipe tomat SSH3 yang suka naungan, genotipe 4974 yang peka naungan (Baharudin et al., 2014; Sulistyowati et al., 2016a) dan generasi F2 hasil persilangan genotipe SSH3 dengan 4974 (F2 SSH3 x 4974) digunakan pada penelitian ini. Penanaman dilakukan pada lokasi tanpa naungan (N0) dan lokasi dengan naungan paranet $50 \%$ (N50). Sebanyak 40 tanaman genotipe SSH3, 40 tanaman genotipe 4974 dan 220 tanaman generasi F2 ditanam pada N0 maupun N50.

Benih tomat disemai pada tray plastik (72 lubang) sebelum dipindah tanam ke bedengan. Media semai yang digunakan merupakan campuran tanah halus, arang sekam dan pupuk kandang 1:1:1. Selama penyemaian, dilakukan penyiraman setiap hari dan pemupukan setiap satu minggu sekali menggunakan pupuk $A B M i x$ dengan konsentrasi 1-2 $\mathrm{ml} \mathrm{L}^{-1}$. Penyemaian dilakukan dalam rumah plastik selama 4 minggu.

Penanaman di lahan dilakukan pada bedengan dengan ukuran $5 \mathrm{~m} \times 1.2 \mathrm{~m}$. Pupuk kandang sebanyak 60 ton $\mathrm{ha}^{-1}$ dan kapur pertanian sebanyak 2 ton ha $^{-1}$ diberikan di bedengan pada 2 minggu sebelum pindah tanam. Mulsa plastik hitam perak digunakan pada penelitian ini untuk mengurangi gangguan gulma dan serangan hama dan penyakit. Penanaman dilakukan dengan jarak tanam $50 \mathrm{~cm}$ x $50 \mathrm{~cm}$. Kegiatan pemeliharaan yang dilakukan selama penanaman terdiri atas pengikatan tanaman ke ajir, pewiwilan tunas air, pemupukan $A B$ Mix $\left(5-10 \mathrm{ml} \mathrm{L}^{-1}\right.$ sebanyak $250 \mathrm{ml}$ per tanaman), penyemprotan insektisida $\left(1-5 \mathrm{ml} \mathrm{L}^{-1}\right)$, fungisida dan bakterisida $\left(1-5 \mathrm{~g} \mathrm{~L}^{-1}\right)$, dan akarisida $\left(1-5 \quad \mathrm{ml}^{-1}\right)$. Pemupukan dan 
penyemprotan pestisida dilakukan 1-2 kali seminggu.

Karakter tinggi tanaman (TT), panjang internode (INT), diameter batang (DBAT), panjang daun (PD), lebar daun (LD), panjang buah (PB), diameter buah (DB), bobot per buah (BB), jumlah buah per tanaman (JBT) dan bobot buah per tanaman (BBT) diamati berdasarkan IPGRI for Tomato. Pengamatan bobot basah daun (BD) dan luas daun (LUD) dilakukan sebanyak 1 daun (daun pada buku ke2 setelah dikotomus) per tanaman. Karakter LUD dihitung menggunakan perangkat lunak ImageJ. Karakter warna hijau daun (SPAD) diamati menggunakan SPAD pada daun ketiga dari pucuk saat tanaman mulai berbunga. Fruit set (FS) diamati dengan membandingkan jumlah bunga yang menjadi buah dengan total bunga yang ada pada 4 tandan bunga/buah pertama, sedangkan karakter bobot daun spesifik (BD/L) dihitung dengan rumus $\mathrm{BD} /$ LUD. Pengamatan dilakukan terhadap semua tanaman yang tumbuh.

Uji t-student dengan taraf $\alpha=5 \%$ dilakukan terhadap nilai tengah genotipe tomat
SSH3 dengan genotipe 4974 baik pada N0 maupun N50 untuk menguji perbedaan nilai tengah karakter antara kedua genotipe. Nilai dan kriteria heritabilitas arti luas (Hbs) dihitung berdasarkan Syukur et al. (2010). Nilai koefisien korelasi pada taraf 5\% dihitung menggunakan korelasi Pearson, sedangkan koefisien lintas dihitung berdasarkan Singh dan Chaudhary (1979).

\section{HASIL DAN PEMBAHASAN}

Hasil uji t-student memperlihatkan bahwa genotipe 4974 menghasilkan panjang daun, lebar daun, luas daun, bobot daun, fruit set, jumlah buah dan bobot buah per tanaman yang nyata lebih tinggi serta tinggi tanaman, diameter batang, bobot daun spesifik dan bobot buah yang nyata lebih kecil dibandingkan genotipe SSH3 pada kondisi tanpa naungan. Karakter panjang internode, kehijauan daun, panjang buah dan diameter buah tidak berbeda nyata antara genotipe 4974 dengan SSH3 pada kondisi tanpa naungan (Tabel 1).

Tabel 1. Nilai tengah berbagai karakter dari 2 genotipe tomat pada kondisi tanpa naungan dan dengan naungan paranet $50 \%$

\begin{tabular}{|c|c|c|c|c|c|c|c|c|}
\hline \multirow{3}{*}{$\begin{array}{l}\text { Karakter } \\
\text { TT }\end{array}$} & \multicolumn{4}{|c|}{ Tanpa Naungan } & \multicolumn{4}{|c|}{ Naungan Paranet 50\% } \\
\hline & \multirow{2}{*}{$\begin{array}{r}\text { SSH3 } \\
63.60\end{array}$} & \multirow{2}{*}{$\begin{array}{c}4974 \\
54.10\end{array}$} & \multicolumn{2}{|c|}{ t-hitung } & \multirow{2}{*}{$\begin{array}{l}\text { SSH3 } \\
111.24\end{array}$} & \multirow{2}{*}{\begin{tabular}{|c|}
4974 \\
73.63
\end{tabular}} & \multicolumn{2}{|c|}{ t-hitung } \\
\hline & & & 2.78 & * & & & 14.00 & $* *$ \\
\hline INT & 9.43 & 8.35 & 1.27 & tn & 14.93 & 13.13 & 1.60 & tn \\
\hline DBAT & 8.49 & 7.17 & 2.76 & $*$ & 7.38 & 7.16 & 0.40 & tn \\
\hline PD & 25.03 & 29.53 & -6.46 & ** & 31.33 & 31.73 & -0.86 & tn \\
\hline LD & 17.83 & 24.60 & -7.68 & ** & 24.26 & 24.06 & -0.30 & tn \\
\hline LUD & 144.11 & 241.47 & -9.83 & $* *$ & 255.39 & 274.21 & -1.70 & tn \\
\hline BD & 7.67 & 10.04 & -9.67 & $* *$ & 9.59 & 9.62 & -0.03 & tn \\
\hline $\mathrm{BD} / \mathrm{L}$ & 0.05 & 0.04 & 9.94 & $* *$ & 0.04 & 0.04 & -0.10 & tn \\
\hline SPAD & 52.43 & 48.40 & 2.09 & tn & 44.11 & 38.15 & 5.30 & $* *$ \\
\hline $\mathrm{PB}$ & 37.80 & 33.46 & 2.09 & tn & 38.78 & 37.31 & 1.49 & tn \\
\hline DB & 36.04 & 32.73 & 2.03 & tn & 34.99 & 36.97 & -1.58 & tn \\
\hline BB & 27.03 & 17.50 & 5.05 & $* *$ & 27.02 & 28.98 & -0.66 & tn \\
\hline FS & 68.82 & 86.67 & -4.97 & $* *$ & 64.93 & 38.90 & 7.50 & $* *$ \\
\hline JBT & 35.94 & 68.37 & -13.04 & $* *$ & 65.42 & 25.60 & 10.00 & $* *$ \\
\hline BBT & 996.76 & 1285.94 & -3.35 & * & 1472.40 & 728.09 & 8.09 & $* *$ \\
\hline
\end{tabular}

Keterangan: TT $=$ tinggi tanaman $(\mathrm{cm})$, INT $=$ panjang internode $(\mathrm{cm})$, DBAT $=$ diameter batang $(\mathrm{mm}), \mathrm{PD}=$ panjang daun $(\mathrm{cm}), \mathrm{LD}=$ lebar daun $(\mathrm{cm}), \mathrm{LUD}=$ luas daun $\left(\mathrm{cm}^{2}\right), \mathrm{BD}=$ bobot daun $(\mathrm{g}), \mathrm{BD} / \mathrm{L}=$ bobot daun spesifik $\left(\mathrm{g} \mathrm{mm}^{-2}\right), \mathrm{SPAD}=$ kehijauan daun (unit), $\mathrm{PB}=$ panjang buah $(\mathrm{cm}), \mathrm{DB}=$ diameter buah $(\mathrm{cm}), \mathrm{BB}$ $=$ bobot per buah $(\mathrm{g}), \mathrm{FS}=$ fruit set $(\%), \mathrm{JBT}=$ jumlah buah per tanaman, $\mathrm{BBT}=$ bobot buah per tanaman $(\mathrm{g}),{ }^{* *}=$ berbeda nyata berdasarkan uji $t$-student pada taraf $1 \%, *=$ berbeda nyata berdasarkan uji $t$ student pada taraf $5 \%, \mathrm{tn}=$ tidak berbeda nyata berdasarkan uji $t$-student pada taraf $5 \%$. 
Genotipe SSH3 menghasilkan tinggi tanaman, kehijauan daun, fruit set, jumlah buah dan bobot buah per tanaman yang nyata lebih tinggi dibandingkan genotipe tomat 4974 pada naungan paranet $50 \%$. Karakter panjang internode, diameter batang, panjang daun, lebar daun, luas daun, bobot daun, bobot daun spesifik, panjang buah, diameter buah dan bobot buah tidak berbedanya nyata antara genotipe SSH3 dengan genotipe 4974 pada naungan paranet $50 \%$ (Tabel 2). Hasil ini mengindikasikan adanya interaksi genetik $\mathrm{x}$ lingkungan (naungan) yang bersifat kuantitatif pada tinggi tanaman, diameter batang, panjang daun, lebar daun, luas daun, bobot daun, bobot daun spesifik, kehijauan daun dan bobot buah serta interaksi genetik $\mathrm{x}$ lingkungan (naungan) yang bersifat kualitatif pada fruit set, jumlah buah dan bobot buah per tanaman. Beberapa peneliti juga telah melaporkan adanya interaksi genetik dan naungan pada karakter jumlah buah dan bobot buah per tanaman (Baharudin et al., 2014; Sulistyowati et al., 2016b), laju fotosintesis, kandungan internal $\mathrm{CO} 2$ (Sulistyowati et al., 2016a).

Karakter tinggi tanaman, panjang daun, lebar daun, luas daun, bobot daun, bobot daun spesifik, bobot buah, fruit set, jumlah buah dan bobot buah per tanaman memiliki nilai heritabilitas yang tinggi, sedangkan karakter lainnya memiliki nilai heritabilitas rendah sampai sedang pada kondisi tanpa naungan (Tabel 2). Mohamed et al. (2012) juga melaporkan nilai heritabilitas dengan kriteria sedang pada bobot buah per tanaman tomat pada kondisi tanpa naungan, namun hal yang berbeda dihasilkan oleh sebagian besar penelitian (Rani dan Anitha, 2011; Saleem et al., 2013; Meitei et al., 2014) yang melaporkan bahwa karakter tinggi tanaman, bobot buah, panjang buah, diameter buah, bobot per buah, jumlah buah per tanaman dan bobot buah per tanaman memiliki nilai heritabilitas yang tinggi pada kondisi tanpa naungan.

Nilai heritabilitas tinggi dihasilkan oleh karakter tinggi tanaman, panjang daun, fruit set, jumlah dan bobot buah per tanaman, sedangkan karakter lainnya memiliki nilai heritabilitas rendah sampai sedang pada naungan paranet 50\% (Tabel 3). Ritonga et al. (2018) melaporkan bahwa karakter fruit set, jumlah buah per tanaman, tinggi tanaman dan ukuran buah memiliki nilai heritabilitas yang tinggi pada pada naungan paranet $50 \%$.

Tabel 2. Nilai komponen ragam, heritabilitas, nilai tengah dan selang beberapa karakter tomat F2 SSH3 x 4874 pada kondisi naungan.

\begin{tabular}{|c|c|c|c|c|c|c|c|c|}
\hline Karakter & Rataan & \multicolumn{3}{|c|}{ Rentang } & $\mathrm{Vg}$ & Vp & $\mathrm{Hbs}$ & Kriteria \\
\hline TT & 59.96 & 36.10 & - & 79.40 & 41.30 & 76.66 & 53.87 & Tinggi \\
\hline INT & 9.09 & 4.80 & - & 14.10 & 1.12 & 3.49 & 32.05 & Sedang \\
\hline DBAT & 8.35 & 6.25 & - & 11.20 & 0.40 & 1.16 & 34.36 & Sedang \\
\hline PD & 25.65 & 14.70 & - & 33.30 & 17.66 & 19.20 & 91.95 & Tinggi \\
\hline LD & 20.77 & 13.10 & - & 29.00 & 10.06 & 13.00 & 77.35 & Tinggi \\
\hline LUD & 178.92 & 56.12 & - & 323.39 & 3198.65 & 3560.73 & 89.83 & Tinggi \\
\hline BD & 8.50 & 4.94 & - & 11.69 & 1.98 & 2.21 & 89.55 & Tinggi \\
\hline $\mathrm{BD} / \mathrm{L}$ & 5.09 & 3.62 & - & 8.80 & 0.01 & 0.01 & 95.39 & Tinggi \\
\hline SPAD & 51.28 & 40.20 & - & 59.40 & 2.60 & 16.09 & 16.15 & Rendah \\
\hline PB & 30.70 & 19.85 & - & 37.07 & 4.26 & 12.08 & 35.25 & Sedang \\
\hline DB & 32.95 & 22.00 & - & 42.13 & 7.83 & 16.80 & 46.64 & Sedang \\
\hline BB & 20.18 & 5.90 & - & 34.30 & 31.33 & 41.94 & 74.70 & Tinggi \\
\hline FS & 86.05 & 52.38 & - & 100.00 & 84.97 & 113.53 & 74.84 & Tinggi \\
\hline JBT & 56.07 & 11.00 & - & 131.00 & 870.62 & 885.28 & 98.34 & Tinggi \\
\hline BBT & 1235.83 & 124.00 & - & 3273.60 & 598076.23 & 608145.93 & 98.34 & Tinggi \\
\hline
\end{tabular}

Keterangan: TT = tinggi tanaman $(\mathrm{cm})$, INT $=$ panjang internode $(\mathrm{cm})$, DBAT $=$ diameter batang $(\mathrm{mm}), \mathrm{PD}=$ panjang daun $(\mathrm{cm}), \mathrm{LD}=$ lebar daun $(\mathrm{cm}), \mathrm{LUD}=$ luas daun $\left(\mathrm{cm}^{2}\right), \mathrm{BD}=$ bobot daun $(\mathrm{g}), \mathrm{BD} / \mathrm{L}=$ bobot daun spesifik $\left(\mathrm{g} \mathrm{mm}^{-2}\right), \mathrm{SPAD}=$ warna hijau daun (unit), $\mathrm{PB}=$ panjang buah $(\mathrm{cm}), \mathrm{DB}=$ diameter buah $(\mathrm{cm})$, $\mathrm{BB}=$ bobot per buah $(\mathrm{g}), \mathrm{FS}=$ fruit set $(\%), \mathrm{JBT}=$ jumlah buah per tanaman, $\mathrm{BBT}=$ bobot buah per tanaman $(\mathrm{g}), \mathrm{Hbs}=$ heritabilitas arti luas $(\%), \mathrm{Vg}=$ ragam genotipe, $\mathrm{Vp}=$ ragam fenotipe. 
Tabel 3. Nilai komponen ragam, heritabilitas, nilai tengah dan selang beberapa karakter tomat F2 SSH3 x 4974 pada kondisi naungan paranet 50\%

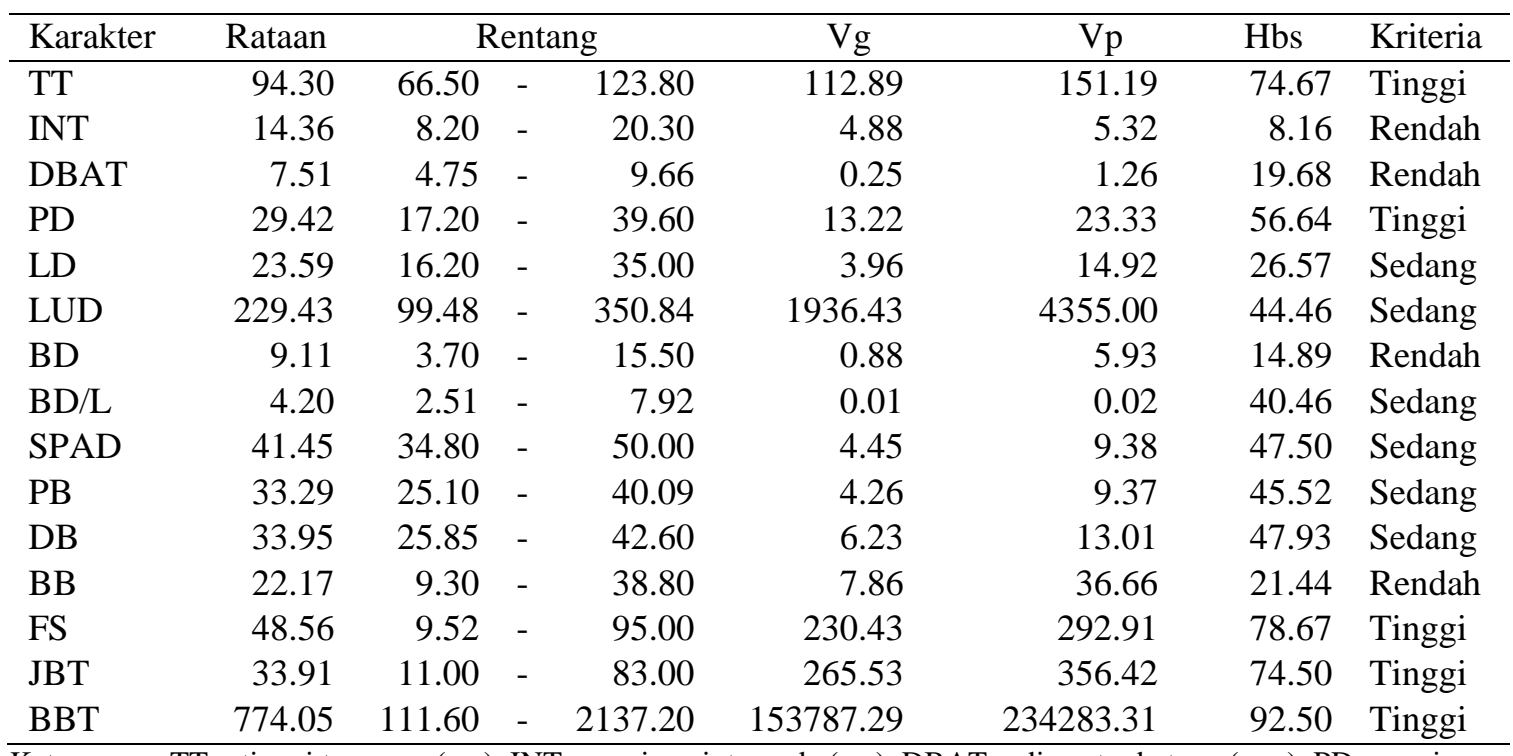

Keterangan: TT $=$ tinggi tanaman $(\mathrm{cm}), \mathrm{INT}=$ panjang internode $(\mathrm{cm})$, DBAT $=$ diameter batang $(\mathrm{mm}), \mathrm{PD}=$ panjang daun $(\mathrm{cm}), \mathrm{LD}=$ lebar daun $(\mathrm{cm}), \mathrm{LUD}=$ luas daun $(\mathrm{cm} 2), \mathrm{BD}=$ bobot daun $(\mathrm{g}), \mathrm{BD} / \mathrm{L}=$ bobot daun spesifik $(\mathrm{g} / \mathrm{mm} 2), \mathrm{SPAD}=$ warna hijau daun (unit), $\mathrm{PB}=$ panjang buah $(\mathrm{cm}), \mathrm{DB}=$ diameter buah $(\mathrm{cm})$, $\mathrm{BB}=$ bobot per buah $(\mathrm{g}), \mathrm{FS}=$ fruit set $(\%), \mathrm{JBT}=$ jumlah buah per tanaman, $\mathrm{BBT}=$ bobot buah per tanaman $(\mathrm{g}), \mathrm{Hbs}=$ heritabilitas arti luas $(\%), \mathrm{Vg}=$ ragam genotipe, $\mathrm{Vp}=$ ragam fenotipe

Nilai heritabilitas penting diketahui untuk menduga apakah suatu karakter lebih banyak dipengaruhi oleh faktor genetik atau lingkungan. Nilai heritabilitas tinggi menunjukkan bahwa faktor genetik lebih besar pengaruhnya terhadap penampilan fenotipe dibandingkan faktor lingkungan. Nilai heritabilitas yang tinggi berperan dalam meningkatkan efektivitas seleksi (Syukur et al., 2010). Berdasarkan hal tersebut, maka keragaman pada karakter tinggi tanaman, panjang daun, lebar daun, luas daun, bobot daun, bobot daun spesifik, bobot buah, fruit set, jumlah dan bobot buah per tanaman lebih dipengaruhi oleh faktor genetik dibandingkan faktor lingkungan pada kondisi tanpa naungan. Kegiatan seleksi pada karakter-karakter tersebut akan lebih efektif dilakukan dibandingkan karakter lainnya pada kondisi tanpa naungan. Hal yang agak berbeda terdapat pada naungan paranet $50 \%$ dimana keragaman karakter yang lebih besar dipengaruhi oleh faktor genetik dibandingkan faktor lingkungan terdapat pada karakter tinggi tanaman, panjang daun, fruit set, jumlah buah dan bobot buah per tanaman. Hal ini mengindikasikan bahwa seleksi terhadap karakter-karakter tersebut akan lebih efektif dibandingkan pada karakter lainnya pada naungan paranet $50 \%$.
Karakter hasil seringkali merupakan hasil interaksi dari berbagai karakter sehingga kegiatan seleksi terhadap karakter hasil dapat dilakukan melalui karakter lain yang memiliki hubungan yang kuat dan positif terhadap karakter hasil (Meena dan Bahadur, 2014). Informasi hubungan antar 2 karakter dapat dilihat dari nilai koefisien korelasi (Tiwari dan Upadhyay, 2011). Hal ini menjadikan nilai koefisien korelasi sangat penting bagi kegiatan pemuliaan tanaman sebagai salah satu dasar dalam penentuan karakter seleksi.

Karakter bobot buah per tanaman memiliki korelasi yang nyata dan positif terhadap diameter batang dan fruit set serta sangat nyata dan positif terhadap panjang buah, diameter buah, bobot buah dan jumlah buah per tanaman pada kondisi tanpa naungan (Tabel 4). Beberapa penelitian melaporkan adanya korelasi yang nyata dan positif antara bobot per buah (Meitei et al., 2014), panjang buah, diameter buah (Rani dan Anitha, 2011) dan jumlah buah per tanaman (Izge et al., 2012; Tasisa et al., 2012; Monamodi et al., 2013; Meena dan Bahadur, 2014) terhadap karakter hasil tomat pada kondisi tanpa naungan. Hal ini menunjukkan bahwa karakter bobot buah per tanaman lebih banyak dipengaruhi oleh karakter buah pada kondisi tanpa naungan. 
Tabel 4. Koefisien korelasi berbagai karakter tomat pada kondisi tanpa naungan (di atas diagonal) dan kondisi naungan paranet $50 \%$ (di bawah diagonal)

\begin{tabular}{|c|c|c|c|c|c|c|c|c|c|c|c|c|c|c|c|}
\hline Kanakter & TI & DNT & DBAT & PD & LD & LUD & BD & BDL & SPAD & PB & DB & BB & FS & IBT & BBT \\
\hline TT & & $0.59 *$ & $0.24^{\circ}$ & $0.56 \cdots$ & $0.43 \cdots$ & $0.51 *$ & $0.51 \cdots$ & $-0.53 \%$ & 0.02 & 0.18 & 0.15 & 0.17 & -0.25 & 0.10 & 0.16 \\
\hline INT & $0.42 *$ & & 0.17 & $0.62 \cdots$ & $0.44 *$ & $0.54 *$ & $0.94 *$ & $-0.58 \cdots$ & 0.12 & 0.24 & $0.255^{*}$ & $0.30^{\circ}$ & -0.19 & 0.11 & 0.23 \\
\hline DBAT & $0.32 *$ & 0.04 & & $0.38 *$ & $0.43 *$ & $0.40 *$ & $0,43 *$ & $-0,44 *$ & -0.16 & 0.20 & $0.25 *$ & $0.30^{\circ}$ & -0.11 & 0.17 & $0.31^{\circ}$ \\
\hline $\mathrm{PD}$ & $0.43 \cdots$ & $0.53 *$ & $0.38 *$ & & $0.81 \cdots$ & $0.94 *$ & $0.94 *$ & $-0.94 \cdots$ & 0.04 & 0.05 & 0.07 & 0.14 & -0.25 & -0.07 & 0.06 \\
\hline LD & $0.39 *$ & $0.43 *$ & $0.44 *$ & $0.78 *$ & & $0.96 *$ & $0.97 *$ & $-0.90 \%$ & 0.03 & 0.12 & 0.12 & 0.15 & -0.02 & 0.07 & 0.16 \\
\hline LUD & $0.38 *$ & $0.45 *$ & $0.41 *$ & $0.93 \cdots$ & $0.94 *$ & & $0.99 *$ & $-0.93 \cdots$ & 0.03 & 0.09 & 0.09 & 0.14 & -0.13 & 0.00 & 0.11 \\
\hline BD & 0.20 & 0.21 & $0.29 \%$ & $0.55 \cdots$ & $0.50 \cdots$ & $0.57 *$ & & $-0.96 *$ & 0.03 & 0.09 & 0.10 & 0.15 & -0.13 & 0.01 & 0.13 \\
\hline BD L & -0.19 & $-0.24^{*}$ & -0.11 & $-0.51 \cdots$ & $0.55 *$ & $-0.55 *$ & $0.92 *$ & & -0.05 & -0.10 & -0.11 & -0.17 & 0.18 & 0.01 & -0.12 \\
\hline SPAD & 0.16 & 0.16 & 0.18 & $0.222^{\circ}$ & 0.16 & 0.14 & 0.12 & -0.05 & & 0.12 & 0.06 & 0.07 & 0.07 & .0 .16 & $=0.13$ \\
\hline Pis & -0.10 & 0.14 & $-0,06$ & 0,06 & -0.05 & 0,03 & 0.19 & 0.17 & -0.01 & & $0.81 *$ & $0.83 *$ & 0.00 & $0.38 *+$ & $0.57 *$ \\
\hline DB & -0.08 & 0.20 & -0.07 & 0.18 & 0.16 & 0.15 & 0.20 & 0.00 & 0.06 & $0.56 *$ & & $0.93 *$ & 0.09 & $0.39 *$ & $0.64 *$ \\
\hline BB & -0.12 & 0.16 & -0.10 & 0.11 & 0.11 & 0.08 & 0.18 & 0.05 & 0.03 & $0.75 *$ & $0.91 *$ & & 0.03 & $0.37 \cdots$ & $0.65 *$ \\
\hline FS & 0.11 & -0.03 & 0.03 & -0.01 & 0.11 & 0.00 & 0.04 & 0.07 & -0.10 & 0.09 & -0.06 & -0.01 & & $0.47 *$ & $0.38 \cdot$ \\
\hline IBT & $0.33 *$ & 0.13 & 0.20 & 0.12 & $0.24^{\circ}$ & 0.16 & $0.27 \cdot$ & 0.14 & -0.14 & 0.17 & 0.04 & 0.10 & $0.66 * 4$ & & $0.92 *+$ \\
\hline BHT & $0.27 *$ & 0.21 & 0.17 & 0.17 & $0.33 *$ & $0.22^{\circ}$ & $0.35 *$ & 0.13 & -0.10 & $0.02 \cdots$ & $0.39 \%$ & $0.47 *$ & $0.58 *$ & $0.90 *$ & \\
\hline
\end{tabular}

Keterangan: $\mathrm{TT}=$ tinggi tanaman, $\mathrm{INT}=$ panjang internode, $\mathrm{DBAT}=$ diameter batang, $\mathrm{PD}=$ panjang daun, $\mathrm{LD}=$ lebar daun , $\mathrm{LUD}=$ luas daun, $\mathrm{BD}=$ bobot daun, $\mathrm{JD}=$ jumlah daun, $\mathrm{BD} / \mathrm{L}=$ bobot daun spesifik, $\mathrm{SPAD}$ = warna hijau daun, $\mathrm{PB}=$ panjang buah, $\mathrm{DB}=$ diameter buah, $\mathrm{BB}=$ bobot per buah, $\mathrm{FS}=$ fruit set, $\mathrm{JBT}=$ jumlah buah per tanaman, BBT $=$ bobot buah per tanaman, ** berkorelasi nyata pada taraf $1 \%$, * berkorelasi nyata pada taraf $5 \%$.

Karakter bobot buah per tanaman memiliki korelasi yang nyata dan positif terhadap tinggi tanaman dan luas daun serta sangat nyata dan positif terhadap lebar daun, bobot daun, panjang buah, diameter buah, fruit set dan jumlah buah per tanaman pada naungan paranet 50\% (Tabel 4). Hal ini mengindikasikan bahwa selain banyak dipengaruhi oleh karakter buah, karakter bobot buah per tanaman tomat juga banyak dipengaruhi oleh karakter daun pada kondisi naungan paranet $50 \%$. Mc Giffen et al (1994) melaporkan bahwa terdapat pengaruh langsung yang kuat antara bobot per buah dan jumlah buah per tanaman terhadap karakter hasil tomat pada kondisi naungan.

Karakter hasil umumnya dipengaruhi oleh banyak karakter lainnya, baik secara langsung maupun tidak langsung. Sidik lintas dapat digunakan untuk mempartisi koefisien korelasi menjadi pengaruh langsung dan pengaruh tidak langsung terhadap suatu karakter. Sidik lintas dilakukan antara berbagai karakter tomat yang memiliki nilai koefisien korelasi yang tinggi terhadap karakter bobot buah per tanaman tomat.

Hasil sidik lintas menunjukkan bahwa pada kondisi tanpa naungan, karakter jumlah buah per tanaman dan bobot buah memiliki pengaruh langsung yang tinggi dan positif terhadap bobot buah per tanaman. Karakter panjang buah dan diameter buah memiliki pengaruh tidak langsung yang tinggi dan positif terhadap bobot buah per tanaman baik melalui jumlah buah per tanaman maupun bobot buah, sedangkan karakter fruit set memiliki pengaruh tidak langsung yang tinggi dan positif terhadap bobot buah per tanaman melalui karakter jumlah buah per tanaman pada kondisi tanpa naungan (Tabel 5). Hasil tersebut mengindikasikan bahwa karakter jumlah buah per tanaman, bobot buah, panjang buah, diameter buah dan fruit set potensial digunakan sebagai karakter seleksi untuk karakter hasil tanaman tomat pada kondisi tanpa naungan. Beberapa hasil penelitian menunjukkan bahwa karakter bobot per buah dan jumlah buah per tanaman memiliki pengaruh langsung yang tinggi dan positif terhadap karakter hasil tomat pada kondisi tanpa naungan (Rani dan Anita, 2011; Tiwari dan Upadhyay, 2011; Monamodi et al., 2013; Saleem et al., 2013; Meena dan Bahadur, 2014).

Selain itu, beberapa penelitian juga telah melaporkan bahwa diameter buah (Saleem et al., 2013; Meitei et al., 2014) dan fruit set (Meena dan Bahadur, 2014) memiliki pengaruh langsung yang tinggi dan positif terhadap karakter hasil tomat pada kondisi tanpa naungan. Namun demikian, Kumar dan Dudi (2011), Tasisa et al. (2012), dan Hidayatullah et al. (2008) melaporkan bahwa tidak terdapat pengaruh langsung yang tinggi dan positif antara bobot per buah dan jumlah buah per tanaman dengan karakter hasil tomat pada kondisi tanpa naungan. 
Tabel 5. Pengaruh langsung dan pengaruh tidak langsung beberapa karakter tomat terhadap karakter bobot buah per tanaman pada kondisi tanpa naungan.

\begin{tabular}{|c|c|c|c|c|c|c|c|c|}
\hline \multirow{2}{*}{ Karakter } & \multirow{2}{*}{$\mathrm{C}$} & \multicolumn{6}{|c|}{ Pengaruh Tidak Langsung } & \multirow{2}{*}{ rXY } \\
\hline & & DBAT & PB & DB & BB & FS & JBT & \\
\hline DBAT & 0.03 & & 0.06 & 0.08 & 0.09 & -0.03 & 0.05 & 0.31 \\
\hline PB & -0.09 & 0.11 & & 0.47 & 0.48 & 0.05 & 0.22 & 0.57 \\
\hline DB & -0.01 & 0.16 & 0.52 & & 0.60 & 0.05 & 0.25 & 0.64 \\
\hline BB & 0.43 & 0.19 & 0.54 & 0.61 & & 0.02 & 0.24 & 0.65 \\
\hline FS & -0.03 & -0.04 & 0.03 & 0.03 & 0.01 & & 0.18 & 0.38 \\
\hline JBT & 0.83 & 0.16 & 0.35 & 0.36 & 0.33 & 0.43 & & 0.92 \\
\hline Sisa & 0.16 & & & & & & & \\
\hline
\end{tabular}

Keterangan: DBAT $=$ diameter batang, $\mathrm{FS}=$ fruit set, $\mathrm{INT}=$ panjang internode, $\mathrm{PB}=$ panjang buah, $\mathrm{DB}=$ diameter buah, $\mathrm{BB}=$ bobot per buah, JBT = jumlah buah per tanaman, $\mathrm{C}=$ koefisien lintas (pengaruh langsung), $\mathrm{rXY}=$ koefisien korelasi terhadap bobot buah per tanaman.

Karakter jumlah buah per tanaman, bobot buah, lebar daun memiliki pengaruh langsung yang tinggi dan positif terhadap karakter bobot buah per tanaman tomat pada naungan paranet 50\%. Karakter tinggi tanaman, lebar daun, bobot daun dan fruit set memiliki pengaruh tidak langsung yang tinggi dan positif terhadap bobot buah per tanaman melalui karakter jumlah buah per tanaman, sedangkan karakter panjang buah dan diameter buah memiliki pengaruh tidak langsung yang tinggi dan positif terhadap bobot buah per tanaman melalui karakter bobot buah (Tabel 6). Hasil tersebut mengindikasikan bahwa karakter jumlah buah per tanaman, bobot buah, fruit set, tinggi tanaman, lebar daun, bobot daun, panjang buah dan diameter buah potensial digunakan sebagai karakter seleksi untuk karakter hasil tanaman tomat pada naungan paranet $50 \%$.
Nilai dan arah koefisien lintas, selisih antara koefisien sidik lintas dengan koefisien korelasi, dan nilai heritabilitas merupakan beberapa pertimbangan yang dapat dijadikan sebagai dasar dalam penentuan karakter untuk kriteria seleksi suatu program pemuliaan tanaman. Karakter yang potensial dijadikan sebagai karakter seleksi adalah karakter yang memiliki nilai duga heritabilitas serta koefisien lintas yang tinggi dan positif. Berdasarkan hal tersebut, maka karakter bobot buah, fruit set, dan jumlah buah per tanaman potensial digunakan sebagai karakter seleksi untuk karakter hasil tanaman tomat pada kondisi tanpa naungan, sedangkan karakter tinggi tanaman, fruit set dan jumlah buah per tanaman potensial digunakan sebagai karakter seleksi untuk karakter hasil tanaman tomat pada naungan paranet $50 \%$.

Tabel 6. Pengaruh langsung dan tidak langsung beberapa karakter tomat terhadap karakter bobot buah per tanaman tomat pada kondisi naungan paranet $50 \%$

\begin{tabular}{|c|c|c|c|c|c|c|c|c|c|c|c|}
\hline \multirow{2}{*}{ Karakter } & \multirow{2}{*}{$\mathrm{C}$} & \multicolumn{9}{|c|}{ Pengaruh tidak langsung } & \multirow{2}{*}{$\mathrm{rXY}$} \\
\hline & & TT & LD & LUD & $\mathrm{BD}$ & PB & DB & BB & FS & JBT & \\
\hline TT & 0.00 & & 0.11 & 0.10 & 0.05 & -0.03 & -0.02 & -0.03 & 0.03 & 0.09 & 0.27 \\
\hline LD & 0.27 & 0.13 & & 0.31 & 0.17 & -0.02 & 0.05 & 0.04 & 0.04 & 0.08 & 0.33 \\
\hline LUD & -0.20 & 0.08 & 0.21 & & 0.13 & 0.01 & 0.03 & 0.02 & 0.00 & 0.04 & 0.22 \\
\hline BD & 0.01 & 0.07 & 0.18 & 0.20 & & 0.07 & 0.07 & 0.06 & 0.02 & 0.09 & 0.35 \\
\hline PB & & -0.04 & -0.02 & 0.01 & 0.08 & & 0.24 & 0.32 & 0.04 & 0.07 & 0.42 \\
\hline DB & 0.11 & -0.03 & 0.06 & 0.06 & 0.08 & 0.22 & & 0.36 & -0.02 & 0.01 & 0.39 \\
\hline BB & 0.24 & -0.05 & 0.05 & 0.04 & 0.08 & 0.35 & 0.43 & & 0.00 & 0.05 & 0.47 \\
\hline FS & 0.03 & 0.06 & 0.07 & 0.00 & 0.03 & 0.05 & -0.03 & -0.01 & & 0.38 & 0.58 \\
\hline JBT & 0.80 & 0.29 & 0.21 & 0.15 & 0.24 & 0.16 & 0.03 & 0.09 & 0.59 & & 0.90 \\
\hline
\end{tabular}

Sisa $\quad 0.32$

Keterangan: $\mathrm{TT}=$ tinggi tanaman, $\mathrm{LD}=$ lebar daun, $\mathrm{LUD}=$ luas daun, $\mathrm{BD}=$ bobot daun, $\mathrm{PB}=$ panjang buah, $\mathrm{DB}=$
diameter buah, $\mathrm{BB}=$ bobot per buah, $\mathrm{FS}=$ fruit set, $\mathrm{JBT}=$ jumlah buah per tanaman, $\mathrm{C}=$ koefisien lintas (pengaruh langsung), rXY = koefisien korelasi terhadap bobot buah per tanaman. 


\section{KESIMPULAN}

Karakter tinggi tanaman, panjang, lebar, luas, bobot daun, bobot daun spesifik, bobot buah, fruit set, jumlah dan bobot buah per tanaman tomat memiliki nilai heritabilitas yang tinggi pada kondisi tanpa naungan. Nilai heritabilitas tinggi di bawah naungan paranet $50 \%$, dihasilkan oleh tinggi tanaman, fruit set, jumlah dan bobot buah per tanaman. Karakter bobot buah dan jumlah buah per tanaman memiliki pengaruh langsung yang tinggi dan positif terhadap bobot buah per tanaman tomat pada kondisi tanpa naungan dan naungan paranet $50 \%$, sementara karakter lebar daun memiliki pengaruh langsung yang tinggi dan positif terhadap bobot buah per tanaman tomat hanya pada naungan paranet $50 \%$. Karakter panjang buah, diameter buah, dan fruit set memiliki pengaruh tidak langsung yang tinggi dan positif terhadap bobot buah per tanaman pada kondisi tanpa naungan dan naungan paranet 50\%, sementara tinggi tanaman memiliki pengaruh tidak langsung yang tinggi dan positif terhadap bobot buah per tanaman tomat hanya pada naungan paranet 50\%. Karakter jumlah buah per tanaman dan fruit set potensial dijadikan sebagai karakter seleksi untuk hasil tanaman tomat pada kondisi tanpa naungan dan naungan paranet $50 \%$, sementara karakter tinggi tanaman potensial digunakan sebagai karakter seleksi untuk hasil tanaman tomat hanya pada naungan paranet $50 \%$.

\section{UCAPAN TERIMA KASIH}

Terima kasih disampaikan kepada Kementerian Riset, Teknologi dan Pendidikan Tinggi atas pendanaan penelitian skema Penelitian Unggulan Strategis dengan (nomor kontrak 083/SP2H/PL/Dit.Litabmas/ II/2015) dan Hibah Disertasi Doktor (nomor kontrak 1561/IT3.11/PN/2018).

\section{DAFTAR PUSTAKA}

Baharuddin, R., M.A. Chozin, M. Syukur. 2014. Toleransi 20 genotipe tanaman tomat terhadap naungan. J. Agron. Indonesia. 42(2): 130-135.
Hidayatullah, S.A. Jatol, A. Ghafoor, T. Mahmood. 2008. Path coefficient analysis of yield component in tomato (Lycopersicon esculentum). Pak J. Bot. 40(2): 627-635.

Ilic, Z.S., L. Milenkovic, L. Sunic, E. Fallik. 2015. Effect of coloured shade-nets on plant leaf parameters and tomato fruit quality. J. Sci. Food. Agric. 95: 2660-2667.

Izge, A.U., Y.M. Garba, I.A. Sodangi. 2012. Correlation ant path coefficient analysis of tomato (Lycopersicon esculentum) under fruit worm (Heliothis Zea Buddie) infetation in a line $\mathrm{x}$ tester. Journal of Environmental Issues and Agriculture in Developing Countries. 4(1): 24:30.

Kumar, M., B.S. Dudi. 2012. Study of correlation for yield and quality characters in tomato (Lycopersicon esculentum Mill.). Electronic Journal of Plant Breeding. 2(3): 453-460.

McGiffen, M.E., D.J. Pantone, J.B. Masiunas. 1994. Path analysis of tomato yield components in relation to competition with black and eastern black nightshade. J. Amer. Soc. Hort. Sci. 119(1): 6-11.

Meena, O.P., V. Bahadur. 2014. Assessment of correlation ant path coefficient analysis for yield and yield contributing traits among tomato (Solanum lycopersicum L.) germplasm. Agric. Sci. Digest. 34(4): 245-250.

Meitei, K.M., G.C. Bora, S.J. Singh, A.K. Sinha. 2014. Morphology based genetic variability analysis and identification of important characters for tomato (Solanum lycopersicum L.) crop improvement. American-Eurasian J. Agric. \& Environ. Sci. 14(10): 11051111.

Mohamed, S.M., E.E. Ali, T.Y. Mohamed. 2012. Study of heritability and genetic variability among different plant and fruit characters of tomato (Solanum lycopersicum L.). International Journal of Scientific \& Technology Research. 1(2): 55-58. 
Monamadi, E.L., D.M. Lungu, G.L. Fite. 2013. Analysis of fruit yield and its component in determinate tomato (Lycopersicon lycopersci) using correlation and path coefficient. Bots. J. Agroc. Appl. Sci. 9(1): 24-40.

Peet, M.M. 1992. Fruit cracking in tomato. Hort Technology. 2(2): 216-223.

Rani, K.R., V. Anitha. 2011. Studies on variability, heritability and genetic advance in tomato (Lycopersicon esculentum Miil.). International Journal of Bio-resource and Stress Management. 2(4): 382-385.

Saleem, M.Y., Q. Iqbal, M. Asghar. 2013. Genetic variability, heritability, character association and path analysis in F1 hybrids of tomato. Pak. J. Agri. Sci. 50(4): 649-653.

Sandri, M.A., J.L. Andriolo, M. Witter, T.D. Ross. 2003. Effect of shading on tomato plants grow under greenhouse. Horticultura Brasileira. 21(4): 642-645.

Singh, R.K., B.D. Chaudary. 1979. Biometrical Methods in Quantitative Genetic Analysis. Kalyani Publisher, New Delhi. Hal: 302.

Sulistyowati, D., M.A. Chozin, M. Syukur, M. Melati, D. Guntoro. 2016a. Selection of shade-tolerant tomato genotypes.
Journal of Applied Horticulture. 18(2): 154-159.

Sulistyowati, D., M.A. Chozin, M. Syukur, M. Melati, D. Guntoro. 2016b. Karakter fotosintesis genotipe tomat senang naungan padaa intensitas cahaya rendah. J. Hort. 26(2): 181-188.

Susilowati, S.H., M. Maulana. 2012. Luas lahan usahatani dan kesejahteraan petani: eksistensi petani gurem dan urgensi kebijakan reforma agraria. Analisis Kebijakan Pertanian. 10(1): 17-30.

Syukur, M., S. Sujiprihati, R. Yunianti, K. Nida. 2010. Pendugaan komponen ragam, heritabilitas, dan korelasi untuk menentukan kriteria seleksi cabai (Capsicum annuиm L.) populasi F5. J. Hort. Indonesia. 1(3): 74-80.

Tasisa, J., D. Belew, K. Bantte. 2012. Genetic associations analysis among some traits of tomato (Lycopersicon esculentum Mill.) genotypes in West Showa, Ethiopia. International Journal of Plant Breeding and Genetics. 6(3): 129-139.

Tiwari, J.K., D. Upadhyay. 2011. Correlation and path-coefficient studies in tomato (Lycopersicon esculentum Mill.). Research Journal of Agricultural Sciences. 2(1): 63-68. 